\title{
Marae Ora Kāinga Ora: Indigenous Health and Wellbeing Solutions via Time-Honored Indigenous Spaces
}

\author{
Jenny Lee-Morgan *, Kim Penetito, Jo Mane and Ngahuia Eruera
}

Citation: Lee-Morgan, Jenny, Kim Penetito, Jo Mane, and Ngahuia Eruera. 2021. Marae Ora Kāinga Ora: Indigenous Health and Wellbeing Solutions via Time-Honored

Indigenous Spaces. Genealogy 5: 99 https://doi.org/10.3390/ genealogy5040099

Received: 13 August 2021

Accepted: 5 November 2021

Published: 17 November 2021

Publisher's Note: MDPI stays neutral with regard to jurisdictional claims in published maps and institutional affiliations.

Copyright: (c) 2021 by the authors. Licensee MDPI, Basel, Switzerland. This article is an open access article distributed under the terms and conditions of the Creative Commons Attribution (CC BY) license (https:// creativecommons.org/licenses/by/ $4.0 /)$.
Ngā Wai ā Te Tūī, Māori and Indigenous Research Centre (NWATT), Unitec, Auckland 1142, New Zealand; kpenetito@unitec.ac.nz (K.P.); jmane@unitec.ac.nz (J.M.); neruera@unitec.ac.nz (N.E.)

* Correspondence: jleemorgan@unitec.ac.nz

\begin{abstract}
Marae Ora, Kainga Ora (MOKO) is a three-year research study established as a marae-led intervention project to strengthen the provision of housing with five urban marae in South Auckland, Aotearoa New Zealand. In brief, marae are primarily places for cultural gatherings and are the centres of activity for Māori communities. Though just one of the marae involved is part of a pre-European tribal settlement, the four other marae were established to meet the cultural needs of Māori who had relocated many decades ago from their tribal areas outside of the Auckland region. The project works with Marae Research Coordinators (MRC) nominated by each marae to build research and development capacity and capability through the sharing of skills, information, and resources. Each MRC is affiliated with their respective marae, either through whakapapa (genealogical links) or through their contributions of service and leadership. The role of the MRC is critical in capturing the lived realities, experiences, and aspirations of their marae community. This was evident in the first year of the project (2020) when three of the five marae actively responded to the needs of their communities during COVID-19 lockdowns in Auckland. While the project has a housing focus, the marae involved demonstrate, in their own distinctive ways, how health and wellbeing is intrinsic to their core function.
\end{abstract}

Keywords: Indigenous methodologies; community-led research; Indigenous housing research; Indigenous community wellbeing; Māori well-being; Marae

\section{Introduction}

Affordable, adequate, and safe housing has become a critical issue globally where quality housing is recognised as key in determining positive health and wellbeing outcomes for people generally (Menzies et al. 2019). In Aotearoa New Zealand, as with many Indigenous and tribal peoples across the world, Māori have, through the process of colonisation, become tenants in their own land (Kelsey 1995). It is forecast that by 2040, $90 \%$ of Māori will be in rental accommodation (Rout et al. 2019). With the high cost of rental housing currently, this is a major concern in terms of affordability and also for the increasing likelihood of Māori homelessness.

Marae Ora, Kāinga Ora (MOKO) is a three-year research project that works with five urban marae in South Auckland. Initiated in 2019, MOKO is a marae-led housing intervention project that aims to develop the provision of kāinga (housing, village, settlement) in the highly urbanised setting of Auckland. With a continuous intergenerational shift from rural, tribal communities to urban, city dwelling communities, the majority of Māori now live in Auckland (Hoskins et al. 2019), the largest city in Aotearoa. These marae work in partnership with Ngā Wai a Te Tūī (NWaTT), Māori and Indigenous Research at Unitec. NWaTT have formed a large Māori research team (13 people) whose members have various tribal affiliations; some of the team members are also affiliated with marae involved in the MOKO project. Each person is highly experienced in working with Māori communities and Kaupapa Māori initiatives, and work with six Marae Research Coordinators (MRC) to 
support and strengthen skills and opportunities that focus on the specific development aspirations of each marae.

As Kaupapa Māori approaches (Smith 1997, 1999; Durie 2004; McIntosh and Mulholland 2011; Workman 2016) aim to create positive outcomes, this research assists in reimagining collective and contemporary development of traditional kāinga. The project conceptualises the co-creation of new community developments based on the notion of ora (Māori notions of wellbeing), and particularly on what can be achieved for the collectives of whānau, hapū, iwi, and the wider community. The MOKO project draws on Māori knowledge systems, including traditions, values, and practices, that strengthen the interdependence between marae ora and kāinga ora (marae wellbeing and community wellbeing), in order to develop a cultural approach to understanding marae-led notions of ora.

Having endured more than 200 years of colonisation, marae have survived as icons of Māori identity and symbols of resilience, with more than 1100 marae currently operating throughout the country (Te Puni Kōkiri 2018). Today, marae and kāinga are diverse, dynamic and complex sites, led by whānau (extended family), hapū (sub-tribal grouping), and iwi (tribe), as well as Māori pan-tribal communities. Marae are considered to be the cornerstones of Māori cultural heritage, and are acknowledged by wider society as a national feature that makes modern-day Aotearoa New Zealand unique (Kawharu 2014).

This research recognises the potential of ancestral knowledge to act as a source of innovative interventions that will facilitate sustainable community wellbeing for marae in a contemporary urban setting now and in the future. Purposefully located in South Auckland, this research aims to make meaningful change for some of the most marginalised and impoverished whānau urban communities in Aotearoa. While South Auckland is rich in Māori and Pasifika peoples (especially young people), languages, and cultures, they also share the hallmarks of poverty, featuring in all the negative social indices of health, education, and justice (Smith 1999; Durie 2004; McIntosh and Mulholland 2011; Workman 2016). As Kaupapa Māori research is committed to transformative outcomes, the MOKO project aims to address Māori social and cultural deprivation through the cultural intervention of marae and kāinga.

\subsection{The Marae Ora, Käinga Ora Project}

MOKO is an apt acronym for our project, 'Marae Ora, Kāinga Ora', because it is the short form of the word 'mokopuna', which means grandchild. The care, safety, protection, and guardianship of mokopuna has traditionally been viewed as a very serious consideration, as the survival of the iwi relied upon it (Eruera and Ruwhiu 2016). Moko are the next generation, they link the past, present, and future together-keeping us focused on the critical elements that will ensure the wellbeing of current and future generations. Similarly, the $\mathrm{MOKO}$ project is focused on the intergenerational sustainability of the knowledge systems and replenishment of cultural and environmental resources, as well as the human and physical infrastructure inherent within marae and kāinga. The Māori saying, 'Matua rautia', which literally means 'a hundred parents', refers to collective living and collective raising of children. It was not uncommon for moko to be raised by their grandparents, uncles, and aunties, as well as their parents. In the same way that many people are expected to care for and educate a child, this project involves collaboration, dedication, and a shared commitment to ensure $\mathrm{MOKO}$ is carefully nurtured and developed. Based on Māori epistemological and ontological constructs of the world (Smith 1997), the MOKO project recognises the inextricable connection between marae ora and kāinga ora, and uses a cultural approach to researching marae-led community wellbeing.

The MOKO project investigates the potential of the five marae to strengthen their provision of kāinga in the contemporary urban context of South Auckland, exploring marae-led initiatives and practices that support and generate whānau and community wellbeing. Such initiatives and practices work to uphold tikanga Māori (cultural practices) in contemporary urban settings in which to retain traditional values related to whenua (land), whanaungatanga (relationships), manaakitanga (care), kaitiakitanga (guardianship), 
and tino rangatiratanga (self-determination), all indicators of collective wellbeing. The five marae fall into three broad categories: mana whenua (tribal) marae, taura here (satellite) marae, and mātāwaka (pan-tribal) marae. They are all located in South Auckland, within the districts of Māngere-Ōtāhuhu, Manurewa, and Papakura.

MOKO seeks to actively contribute to the replenishment of marae and the nurturing of kāinga in order to create positive impacts for their communities. The key aims of this project are twofold: to enable marae to utilise the findings of this research to develop sustainable marae-led kāinga initiatives in and with their communities; and to provide insights and influence opportunities for others, including external agencies, services, and other marae. This would help to achieve greater outcomes and collaborative advantages for whānau and community wellbeing.

\subsection{Marae and Kāinga: Māori Community Sites}

Marae, alongside kāinga, are the original physical configurations that housed the kinship groupings that have survived the test of time, albeit in modified forms today. Traditionally, marae are the heart of the kāinga, which refers to the village and collective way of life (Hoskins et al. 2019). Where marae are seen as a focal community hub, it was the kāinga that provided all that was required for the marae to operate. Just as all things in the Māori and Indigenous worlds are connected, the marae and kāinga had a particular social interdependency. In the Māori world, there is a clear demarcation between tapu (sacred) and noa (common), ceremonial rituals and everyday practices, esoteric and exoteric knowledge, the spiritual and physical realms, and the individual and collective responsibilities (Royal 2003). The nexus between these things are exemplified, moderated, and managed through the relationship between marae and kāinga.

Māori connection to the marae is part of understanding Māori wellbeing. In the Deloitte report 'He Oranga mo Aotearoa: Māori Wellbeing for All', Lloyd affirms that Māori wellbeing is qualitatively different, based on "our status as tangata whenua [people of the land / Indigenous people]—in order to succeed we must succeed as Māori" (Lloyd 2018 , p. 2). While marae are highly valued by Māori communities as being critical to cultural sustainability; and acknowledged by government agencies as important community providers, there is a dearth of research about how contemporary urban marae operate, and about how they can work with, and for, communities. Deloitte's State of the State: NZ 2018 (Lloyd 2018) papers make it explicit that the Treasury's Living Standards Framework offers an opportunity for a more holistic approach to wellbeing. MOKO provides the opportunity for marae and communities to develop culturally relevant strategic designs based on community aspirations and resources that also engage stakeholders to ensure the intergenerational sustainability of marae and community (marae ora and kāinga ora). With a history of failed government approaches to improving Māori wellbeing (Lloyd 2018), Māori innovations, such as marae-led interventions founded on mātauranga Māori (Māori knowledge systems), are required to achieve meaningful progress.

\subsubsection{Marae}

The marae is a physical, cultural, and spiritual space of belonging, and it is the centre of Māori cultural activity and formal ceremony for each tribal group. As Tapsell explains, "When evoked, it [marae] is a physically bounded three-dimensional space, capable of spiritually joining Papatūānuku (land) with Ranginui (sky) into which ira tangata (the human principle) may enter and commune with ira atua (the divine ancestors)" (2014, p. 141). Ancestral connections, transmission of cultural literacies, the debating of tribal politics, and the practice of time-honoured traditions continue to be exchanged in the space known as marae (Salmond 1994; Bennett 2007; Adds et al. 2011; Ka'ai 2008).

The word 'marae' is most commonly understood as it is defined in the Williams Māori Dictionary, as "an enclosed space in front of a house, courtyard, village common". However, the word 'marae', as an adjective, also refers to "being generous or hospitable" an indication of the primary purpose of the marae. (Williams 2015, 7th ed. s.v. "marae."). 
The etymology of the word 'marae' also signals the importance of this space and place in our lives. In conversation with the author 30 August 2019, Eruera Lee-Morgan shared, the word 'marae' can be broken most simply into two parts, 'ma' and 'rae'. Literally, 'mā' means to be clean, freed from tapu. 'Rae' is the word for the forehead, or temple one's head being the most sacred part of one's body. (Williams 2015, s.v. "mā.".s.v."rae.") This perspective of marae broadens our understanding beyond the physical place and structure, and emphasises the importance of the marae as a space to ceremonially cleanse, a space to gather, listen, talk, and clarify thinking-marae epitomises places of wellbeing and, in its broadest sense, has the power to heal.

\subsubsection{Kāinga}

Whereas the word 'kāinga' is often used to refer to a house or home, traditionally the kāinga was not a singular dwelling, but rather referred to the home of the whānau, who lived in clusters of dwellings. Communal facilities that included marae were a feature of the kāinga. The kāinga was 1the community in which Māori lived in relation to each other, as well as the personified natural environment. From Ranginui (Sky Father) and Papatūānuku (Earth Mother), all living things are connected in the Māori world (Royal 2003).

Our language again provides an insight into the cultural notion of the kāinga as a village. The (Williams 2015, s.v. "kāinga.") refers to kāinga as, among other things, "a place where fire has burnt". The reference to fire is encrypted in the first part of the word, ' $k \bar{a}$ ' - to be alight. If 'ngā' in 'kāinga' refers to 'the' (plural), then kāinga can also be interpreted as 'the burning fires'. This acknowledges the importance of fire to our traditional way of life, as signified in other words, such as 'ahi kaa' (home fires), which refers to the home people who continue to occupy and care for ancestral lands. The kāinga, or land settled by a whānau, hapū, and/or iwi, would be evident by the signs of habitation and occupation (of fire sites). Another interpretation of 'kāinga' is taken from the two parts of the word 'kai' (food) and 'ngā' (the, plural), which suggests that kāinga were literally established in close proximity to sources of food and sustenance (Hoskins et al. 2019, p. 10). Kāinga refers to our homelands-our place of belonging where Māori are deeply connected to the living space itself. Kāinga interacts seamlessly with the natural environment, and supports our cultural ways of living as Māori. Kāinga are unique Māori settlements that are structured in ways that reflect Māori lives, and the centrality of collective living in particular.

The importance of the kāinga is noted in the Treaty of Waitangi, the founding document of New Zealand society today. Signed in 1840 by the Crown and rangatira (chiefs) of many tribes throughout New Zealand, the Treaty of Waitangi was an agreement between Māori as tangata whenua (people of the land) and the British Crown. Though the English and Māori versions of the treaty differ, it is the Māori version, Te Tiriti o Waitangi, that takes precedence under the law of 'contra proferentem' (Suter 2014) in terms of what would have been understood by the Māori rangatira who signed it. In te reo Māori version of the Treaty (Waitangi Tribunal n.d.), Article 2 states:

Ko te Kuini o Ingarani ka wakarite ka wakaae ki ngā Rangatira ki ngā hapū-ki ngā tangata katoa o Nu Tireni te tino rangatiratanga o ratou whenua o ratou kāinga me o ratou taonga katoa.

The Queen of England agrees to protect the chiefs, the subtribes and all the people of New Zealand in the unqualified exercise of their chieftainship over their lands, villages and all their treasures.

It is clearly evident that Māori were guaranteed the 'highest chieftainship' of their kāinga, ensuring the continuation of Māori ways of living in our land, based on our cultural knowledge systems, and the cultural narratives storied in our ancestral land and seascapes.

Despite the promises made in the Treaty of Waitangi to Mãori, the force of colonisation was based on the exploitation and dispossession of Māori of their lands and resources (O'Malley 2019; Walker 1990; Belich 1986). This had a devastating impact on the kāinga and marae, which is reflected in the trauma experienced by Māori people (Barnes and Mc- 
Creanor 2019; Wirihana and Smith 2014). Colonisation disrupted and destroyed communal and intergenerational living, and genealogical affiliation to land and landmarks, and led to the loss of spiritual, cultural, and economic connection to land and the natural environment. This further affected the demise of the status and value of Māori language, cultural practices, and knowledge, including the delegitimisation of Māori healing practices and concepts of wellbeing. Key to the process of colonisation was the undermining of Māori belief systems and the repression of our ability to assert customary lore (Mikaere 2011; Te Aho 2007).

Government laws and policies across the spectrum of society unhinged the fabric of kāinga that relied on communal use of land and natural resources and collective ways of living. The movement from living within the kāinga to nuclear-family-sized housing set about changing the ways in which Māori needed to cohabit alongside Pākehā (see glossary). By the 1950s, the phenomenon that would exponentially change the imminent cultural landscape for whānau Māori was to be experienced. Post-World War Two, the migration of Māori from rural to urban living was "stimulated by the state" (Hokowhitu 2013 , p. 357). In order to survive in an economic climate that had no place for tribalisation, subsistence living from the land, and traditional land values, Māori were encouraged to "leave the papakāinga (original home-base) and marae (centre of Māori social life) for towns and cities" (Walker 1990, p. 97). The implications for kāinga and marae would involve the transplanting of the sociocultural system of whānau, hap $\bar{u}$, and iwi into a very different societal context. As the pull to the urban environment became a move necessary for whānau to survive, it was taken for granted that the traditional kāinga that Māori had left behind in the country had fostered cultural habits that needed to be purged and replaced with modern Pākehā customs and values (Williams 2015, p. 94).

As marae evolved in the late 19th century to become a set of communal buildings surrounding the marae ātea, individual kāinga (homes) became progressively more separated from the pā kāinga (Tapsell 2014). Today marae often stand in isolation from their tribal kāinga through urbanisation, and many urban marae are now dislocated from their original Māori communities through inner-city growth and gentrification (Awatere et al. 2008; Tapsell 2002). According to Te Puni Te Puni Kōkiri (2018), there are approximately 1100 marae operating throughout Aotearoa, with 75 marae in Auckland. Of these, 38 are in South Auckland and service approximately $80 \%$ of the total Auckland Māori population (Te Puni Kōkiri 2018). There are currently five primary types of marae, with urban Māori communities at the forefront of this evolution: hapū marae, national marae, mātāwaka marae, taura here marae and institutional marae (see Glossary). While marae have always been central to Māori whānau and communities, the value of marae in Aotearoa is beginning to be recognised more widely. Marae are now included in the New Zealand housing continuum (Hoskins et al. 2019) as a source of resilience for whānau and communities, and are identified as a key focus for Māori identity and wellbeing in the Auckland Plan 2050 (2018) by local government.

Marae may have become more publicly visible recently because of their provision of emergency shelter (Hoskins et al. 2019) and support in times of civil emergencies and crisis, but they have always been active community hubs. While some marae may be seen to be flourishing, the institution of marae is considered by many to be in crisis (Tapsell 2002; Kawharu 2014; Tapsell 2014). Not only are many of the buildings in disrepair with insurance becoming increasingly expensive, our kaumātua (with the cultural knowledge to ensure proper kawa and tikanga, including the tapu and noa sanctity of the marae) are becoming scarce, and many marae are burdened with financial, political and legal issues (Kawharu 2014). Marae are fully dependent on the next generations within the tribal community group, most of whom no longer live in kāinga or close to their marae, to take up key roles. Kawharu rightly describes our marae and language as being in "vulnerable states" (Kawharu 2014, p. 6). Whereas kāinga in traditional times resourced the marae, marae today (as one of the few culturally demarcated sites remaining) are 
now expected, but struggle, to adequately service kāinga within high-needs communities (Hokowhitu 2013).

Marae have been developed and transformed over hundreds of years to adapt to the changing face of Māori populations, and are considered as vital cultural spaces for safety and refuge to ground the multiple identities of Māori and diverse Māori realities that have also evolved (Durie 1994; Durie 1998). As Bennett explains, "In the prosaic world, the marae remains a fluid, amorphous entity that has adapted to vast change and will continue to do so ... the marae is of us. The marae is us" (Adds et al. 2011, p. 242). Unfortunately, this is not fully realised in the ongoing housing discussions. In a recent Crown-funded research initiative, known as the Building Better Homes, Towns and Cities (BBHTC) Challenge, marae are not exclusively mentioned in the plethora of Māori stakeholders included as essential respondents to the housing crisis. Despite the Māori expertise involved and commitment to Indigenous innovation and opportunity to co-create solutions, our marae are still not fully appreciated as standalone entities that function as indicators of whānau, hapū, iwi, and kāinga wellbeing (Building Better Homes, Towns and Cities 2015).

\section{Materials and Methods}

\subsection{Methods: Creating Collaborative Partnerships with Five Marae}

The chosen raft of methods selected by the research project is grounded in tikanga Māori principles relevant to the engagement and maintenance of relationships. Operating within the cultural parameters of a Kaupapa Māori research approach, it is critical to ensure that multiple layers of influence and relationships in, and with, the marae partners are recognised as central to levels of project participation, engagement, collaboration, analysis, and success (Smith 1997). The indicators of success, therefore, not only account for an initial investment of time at the outset, but they are considered the foundations of a long-term exchange and transference of knowledge, experience, and capability of mutual benefit to all parties, beyond the duration of the research project.

The idea for the MOKO project came about from research (Lee-Morgan et al. 2019) undertaken with Te Puea Marae, who have been providing shelter for homeless families in Auckland, and with whom the foundations of this relationship have been created. Te Puea Marae brought national attention to the situation of homelessness and the shortage of housing in the Auckland region by providing shelter and support for homeless families to access housing. The success of Te Puea Marae in securing homes for homeless families became a natural lead-in to explore the potential of other urban marae to consider housing solutions for their marae communities.

The success of Kaupapa Māori as a methodology to capture the learnings from the Te Puea Marae homelessness-relief experience has influenced the chosen approach for the MOKO research project.

In more recent literature, Kaupapa Māori as a theory and as a practice has been critiqued on the basis that all research methodologies evolve, and that Kaupapa Māori belongs in both academia and in the community (Eketone 2008). This critique emerged building on the original writings of Graham Smith (1997). As Eketone explains, the theoretical underpinnings of Kaupapa Māori are informed by two differing theoretical perspectives: critical theory, which originates from Marxism and challenges and transforms oppressive structures; and constructivism, where knowledge is validated through a social construct of the world that is local and specific. Both approaches contribute key components necessary to assert the advancement of Māori and their development as Māori. In particular, Kaupapa Māori practice and Kaupapa Māori research highlight social injustice and promote emancipation, empowerment, and self-determination through the analysis of power dynamics and resistance. This assertive approach to privileging Māori knowledge, values, and processes is a positioning that responds to the historical context and impact of colonisation on Māori societal constructs, through to the present time. The resilience that Māori communities have evolved to within urban settings has been sustained by the reconstruction of traditional knowledges, adapted to be able to advance in a completely different cultural context. 
Community-based participatory research (CBPR) methodology aligns with that of Kaupapa Māori and replicates this phenomenon with the MOKO project, whereby Māori researchers are able to weave the principles of two theoretical worldviews together to interact with and observe multiple development advantages within marae and with community wellbeing. This alignment is discussed in more detail later in this article.

The project has worked from the outset as a collaboration with marae leadership; this is detailed in the following section and discussed further under each of the key methods:

- An understanding of the research intent and engagement of key relational stakeholders with each marae is an essential component to advancing the project's desired outcomes;

- $\quad$ Partnering with marae means marae-based priorities are determined by marae leadership in this research, in which Kaupapa Māori approaches seek positive, practical outcomes;

- Wānanga asserts a culturally preferred pedagogy that ensures Tikanga Māori (Māori cultural protocols), mātauranga Māori, and Kaupapa Māori principles guide ethical practice and decision-making.

Stakeholders: The key internal stakeholders included the Whānau (marae community) and Board of each Marae and the Kahui Advisory Group, whose membership holds expertise in understanding and articulating the needs of their local communities. With Te Puea Marae already heralded as a successful homelessness and housing initiative, their involvement and experience at the inception of the MOKO project provided significant foundation and insight. Ngā Wai a Te Tūì actively canvassed potential marae about the need for this kind of research project. Marae responded positively in recognising that the MOKO project would add another important layer of evidence relevant to marae capability and their development needs, which would enable them to participate and contribute in a variety of ways to housing provision or housing development options. Each marae identified internal stakeholders as well as external stakeholders that they partnered with or worked closely with from government, community, or local business, including funders. The processes that occurred during development are discussed elsewhere in this article. Other marae stakeholders (external) were identified as one of the activities for the MRCs in Year One of the project. External stakeholders were suggested by each marae and are being interviewed currently in Year Two of the project.

Partnering with Marae: As a Kaupapa Māori research project working with marae, the initial development of the idea of working in partnership with each marae was crucial. The selection process to decide which marae would be approached was based on identifying marae that the research team were confident that they had an existing relationship with. Another criterion considered was that these marae were established social-support hubs in their communities and were positioning themselves to respond more proactively to whānau needs through the development of land and potential housing opportunities. A number of meetings with the leadership, governance, and whānau of each marae was necessary to ensure the intent of the research was fully understood and the expectations of both parties, in respect of positive outcomes for the marae, were agreed to.

Importantly, Kaupapa Māori research approaches align strongly with the principles of CBPR in terms of building on the strengths and resources of the community and facilitating collaborative partnerships in all phases of the research (Israel et al. 2010). The MOKO project ensured that this was an authentic collaboration on all levels and at all stages of the research. Having secured agreement with five marae to become partners in $\mathrm{MOKO}$, it was essential to formalise this through ritual, in a blessing ceremony or 'tohi', to publicly acknowledge the launching of the marae partnership with NWaTT, Unitec, New Zealand. The celebration of the MOKO project was hosted at Te Noho Kotahitanga Marae, Unitec. This event brought together representatives from the five marae, stakeholders/partners with each marae who had a vested interest in the research outcomes, and the wider research team, to witness the signing of a Memorandum of Understanding. Tony Kake, CEO of Papakura Marae, commented on the day, "there's an urban marae story that needs to be 
told ... when we talk about kāinga it was never about walls and beams, it's about hopes and dreams for our whānau" (Tony Kake, speech at event, 19 March 2020). All marae partners spoke about their enthusiasm to be a part of a collaboration that had the prospect of maximising positive outcomes for whānau Māori and consequently their surrounding communities.

Indicators of progress and a sense of achievement for the research team in partnering with marae has been monitored in particular in the first year of the research project to ensure the foundations of co-management and co-responsibility to the research were evident. This would manifest as more meaningful and open dialogue with the leadership in each marae. As each marae is expected to host a MOKO project full-team hui over the three years, the experience of participating in the four marae hui that have eventuated to date has been highly successful. These marae have fully taken advantage of this time to showcase their marae history, their activities, and their future planning priorities-a clear level of trust and confidence in their partnership with the NWaTT team.

\subsection{Marae-Based Researchers: Establishing Ngā Puna o Ngā Marae}

As marae-led research, the MOKO project required marae-based researchers to be selected. These roles were identified as Marae Research Coordinators (MRC). Each of the marae nominated their researcher, with a priority criterion to be named as 'the connector and coordinator' in each marae community, who held strong working relationships within the whānau internally and with external parties in the wider community. This reiterates the strength of the situated insider-outsider researcher that Kaupapa Māori research embraces (Smith 1999). The Kaupapa Māori principle of āta (growing respectful relationships), developed by Pohatu (2013), ratifies the absolute proficiency of the partner marae to exercise their knowledge of the expertise of individuals within the collective, to appoint accordingly. Where this was not so straightforward for marae to pinpoint this quality in one individual, or where there were a number of interested people in the running who fit the specifications of the role, we worked together with two of the marae to run a selection process. One of the five marae decided that they wanted to support two people working in the role, which we felt necessary to help make this possible, and a job-share situation was negotiated. It took three months to appoint six MRCs for the five marae.

The COVID-19 pandemic coincided with the appointment process, so much of the communication to establish these marae-based researchers was conducted via Zoom and email. While this was long and sometimes difficult online, it was vitally important to gel this group as early as possible in the project once they were all appointed. One of the first tasks for the collective of MRCs was to name themselves and claim their identity in this research journey. By way of discussion over several hui, the name Ngā Puna o Ngā Marae (NPNM) came to fruition. This identifies their value as the spring of knowledge or the source of information (ngā puna) of the marae.

Our approach was to bring the group together as frequently as possible (weekly) and solidify their collective fortitude to work together. The initial online meetings were centred on nurturing a rapport within the NPNM. Understanding their own value of what they brought to the MOKO project individually and as a collective was achieved through numerous conversations and discussions to share their experiences and encourage more in-depth exploration about the things that shaped their worldview and their perspectives.

A deliberate approach to ground understanding about the MOKO project was to provide a close working relationship with experienced researchers. Marae Leads were assigned to each NPNM from the NWaTT team. Their role was to meet fortnightly with the NPNM and be the first point of contact for the role and their marae as part of the MOKO research project. The Marae Leads each possessed diverse knowledge and experience in their disciplines. They have been tasked with growing the marae whānau research capability alongside the capability of the NPNM. Among many things, NPNM found that this one-to-one exchange with experienced researchers stimulated and challenged them to think critically, so as to further inform their analysis in any given situation. Building on the 
resources on hand to grow the marae-based research group required a commitment to a weekly Zui (Zoom hui) online meeting. This forum was set up to ensure a safe and open space for the NPNM to meet each other, discuss issues, collectively find solutions, share information, and gain support in progressing through their work schedules and milestones. This was a facilitated forum that occurred twice a week while Aotearoa was affected by COVID-19 restrictions. Tikanga Māori protocols facilitated our coming together by leading every hui and meeting space with mihimihi (greetings and acknowledgements), karakia (opening and closing acknowledgments to a higher spiritual force), and whakawhanaungatanga (individual expressions of connection and update). A one-hour session to keep the group socially connected and to check in with individual wellbeing ensued. A two-hour mid-week wānanga provided further learning opportunities and a place to have a variety of research experts speak about their passion projects.

As with the dedication to the partnering with marae, the building of a collaborative working relationship with the MRCs would be an equal investment of time and energy as guided by the obligations of Kaupapa Māori methodology. The visible rapport created between the MRCs and with the wider MOKO research team became obvious through the depth of sharing and reflection on various research activities that were engaged in over the past two years. As a collective, discussions have progressed to analysis, observations, solution seeking for common issues shared across marae, and a confidence to contribute learnings to research conference presentations. MRCs have actively provided the channel through which each marae has been able to work directly with some of the specialist researchers in the MOKO team to seek their professional advice and guidance relative to progressing specific marae development aspirations.

Increased communication and the sharing of information and resources between the five marae, especially during COVID-19 lockdowns, can be attributed to the success of this forum, the confidence in research capability gained, and the recognition from MRCs themselves that they are key assets to both the project and their marae.

\subsection{Wānanga}

Wānanga is a key methodological practice in this research process. Situated in Māori cultural norms, wānanga is considered by Smith, Pihama, Cameron, Mataki, Morgan, and Te Nana as a decolonising process where knowledge is shared and outcomes are made useful for Indigenous communities (Smith et al. 2019). In this case, wānanga enables a sharing of research knowledge with those that have helped to create it. Traditionally, wānanga were forums for discussing tribal knowledge (Smith et al. 2019; Israel et al. 2010); however, wānanga over the last 30 years or so have been used as a mode of learning that facilitates high levels of participation and sharing for all involved. As we experienced in the MOKO project, one of the most credible benefits of wānanga is the sharing of knowledge and practice across contexts, in a culturally safe and supportive space (Smith et al. 2019).

With the situation of COVID-19 in the first year of the project as it was, it was usual for wānanga to be online. Zoom breakout rooms, established prior to each speaker presentation, helped participants prepare their thoughts for the session. Speakers also provided provocations as part of their presentations that required the group to break into pairs to discuss further and bring back any contributions. This practice of reflection, alongside a journaling of their MOKO research experience, led to an increased confidence and proficiency for participants in articulating the project to others and helping them firmly understand the part they played.

A debrief of each wānanga the following week brought together feedback that came from this highly engaged level of participation with the research experts. Statements from NPNM participants acknowledge the mutual understanding of what potential gain there is for the marae participating in the project, and how they are key conduits to the possible repercussions for their marae.

The wānanga approach to the MOKO research project brings a culturally relevant form of teaching and learning exchange for marae and researchers. Reciprocity of knowledge 
and experience is an essential element to the wānanga learning environment. The characteristics of wānanga are captured in the Education Act 1989, which states, "a wānanga is characterised by teaching and research that maintains, advances and disseminates knowledge and develops intellectual independence, and assists the application of knowledge regarding ahuatanga Māori (Māori tradition) according to tīkanga Māori (Māori custom)" (p. 162, 4 [b ?, ivB11-genealogy-1360049).

As one of the MOKO methods, wānanga has enabled a broader participation of marae communities, as demonstrated through the marae-hosted wānanga outcomes. This engagement and shared opportunity to gain new knowledge from each other through the collaborative processes outlined in CBPR has seen indicators of transformation and increased participation from the marae communities, attributed to greater understanding and a sense of inclusion.

\section{Discussion}

MOKO is a Kaupapa Māori research project co-created with marae, utilising mātauranga Māori to reimagine kāinga (communities), specifically in the South Auckland area. Kaupapa Māori methodologies and theory (Pihama et al. 2002; Smith 1999) underpin our work as Māori researchers, and assert the legitimisation and normalisation of Māori epistemological and ontological constructions of the world (Smith 1997). A Kaupapa Māori approach is critical to ensure that multiple layers of influence and complex cultural relationships in and with the marae are recognised as central to levels of project participation, engagement, collaboration, analysis, and success (Smith 1997). Each marae constitutes its own microsystem in its dynamics and politics of whānau and whakapapa relationships, as well as a range of cross-sectorial working relationships and partnerships with external agencies. Kaupapa Māori methodology directly aligns to the kaupapa of this research project, the research methods, and the ways in which new knowledge will be protected and disseminated for the greatest potential transformative impact.

Marae-led community development and wellbeing (kāinga ora) is at the core of this research project, which aligns with a CBPR approach that makes the marae and community central to all dimensions of research. A co-creation approach to research activities ensures outcomes based on understandings and frameworks of local kāinga ora and helps meet the needs and aspirations of the marae and community. Essentially, the MOKO research engages through the five marae with whānau, communities, and key stakeholders in South Auckland.

This research provides the opportunity to develop a framework for marae-led community wellbeing that takes into account Māori models (McClintock et al. 2013) of best practice, and will develop marae-based community wellbeing indicators. From a holistic approach to understanding long-term sustainability, kaitiakitanga (Lloyd 2018) is the traditional practice of guardianship of the natural world, whereas manaakitanga is usually more specific to showing generosity and care for people (Pohatu 2013). Kaitiakitanga and manaakitanga principles will provide ways of investigating the needs, risks, and opportunities in cultural, physical, and operational infrastructure. Both are key responsibilities of traditional practice and are also essential aspects of this research approach. Both traditional and contemporary understandings inform the development of community connectedness and wellbeing. The project recognises the wide range of activities marae are already engaged in with community groups, including other ethnicities though especially Pasifika (Pacific Island) communities. The distinctive added cultural value that marae contribute also acknowledges other cultural contexts. Many of the marae activities in progress are supported through partnerships and collaborations with government agencies, social services, and local councils.

As with Kaupapa Māori, a CBPR approach aims to replenish the marae as sources of sustenance and to strengthen connectedness to kāinga, for community wellbeing and whānau resilience. It is an opportunity to undertake research by, for, and with marae and communities to contribute to the strategic and collective development of kāinga ora 
for whānau and community. This research is driven by Māori priorities and needs, is consistent with tikanga Māori, and will generate mātauranga that is highly valued and used by marae, communities, service providers, and council and government agencies, including the education, health, and social service sectors.

Enabling marae, communities, and stakeholders to be an active part of developing the solutions and co-production of new knowledge and dissemination activities (Smith et al. 2019) is critical for this research to have maximum impact. Community participation is a prerequisite to understanding and enhancing community wellbeing and kāinga. Our multidisciplinary Māori research team is well positioned to utilise a Kaupapa Māori research approach that relies heavily on our existing whanaungatanga relationships and professional networks. Together with our ability to develop further relationships and meaningful community participation, we can co-produce transformative outcomes.

Using a Kaupapa Māori approach alongside CBPR, this project is a mixed-methods study (both quantitative and qualitative) exploring the ancient Indigenous innovation of marae and kāinga to understand and co-create new, culturally based initiatives to activate community development and wellbeing.

A CBPR approach has a number of similarities to the theoretical stances and practices of Kaupapa Māori research. In particular, it is focused on building the skills and strengths of the community to undertake their own research (Mane 2009). Thus, the research is grounded in the community of interest, as with the MOKO project. With both Kaupapa Māori and CBPR, 'tino rangatiratanga' or self-determination is a key principle that specifies research as by, for, and with its community of interest, therefore building the capacity and capability of whānau, hapū, iwi, and the wider community. Growing community-based research, where researchers have a strong sense of community or kinship ties to their communities, is a positive outcome, in that researchers based in their own communities or tribal regions are more likely to have specific understandings of the research needs and aspirations of those communities (Mane 2009).

Kaupapa Māori methodology (Mane 2009; Mahuika 2008; Pihama 2012; Israel et al. 2010; Smith 1997,1999) directly aligns to this research project and the research methods, as well as the ways in which new knowledge will be protected and disseminated for the greatest potential transformative impact. Marae are centres for resilient communities, and the extension of the lessons of targeted kaupapa research to other struggling urban communities has significant potential to be of benefit to New Zealand. Replenishing marae that are supported by nourishing kāinga will have a positive impact on the communities they serve, and the lessons from this transformation will benefit wider New Zealand. The Ministry of Māori Development, Te Puni Kōkiri, states in their 2018-2022 strategic intentions document that kāinga are one the five significant priorities for Māori, and that they seek to implement lessons in policy and practice for the future (Te Puni Kōkiri 2018). The value of marae is also recognised by Auckland Council, who have found marae to play a leadership role in enabling better outcomes for Māori and for the wider community (Auckland Council 2018). In order to expand this evolving role, more resources and support for marae are needed. This support, according to Auckland Auckland Council (2018), will include developing governance, management, and the physical infrastructure of the marae. It will also mean creating effective partnerships with marae. These dimensions are a part of the research design of MOKO. This research project will go beyond the expected government and council directives, and result in research outputs that support marae, their communities, and stakeholders in South Auckland, and are applicable to all of New Zealand.

\section{Results}

The specific research problem that $\mathrm{MOKO}$ is actively generating a response to relates to the historical oversight in the Aotearoa New Zealand political landscape, in particular to observation that Māori capability and knowledge systems exist to provide innovative solutions to social issues for communities. With a history of failed government approaches 
to improve wellbeing (Lloyd 2018), Māori innovations, such as marae-led interventions founded on mātauranga Māori knowledge systems, are required to achieve meaningful progress. Māori have the answers and, through cultural interventions such as marae, can address the existing social, economic, and cultural deprivation of Māori in the urban context (Lloyd 2018).

The MOKO project hypothesises that Māori communities cohere around the marae and the notion of kāinga ora as the basis for wellbeing. Marae have the capacity to assume central roles in the provision of critical culturally based housing initiatives as kainga that can support and enhance Māori whānau lives in the city, and inform a new way of understanding the role of urban marae in Auckland.

This project relies on a multi-disciplinary team with strong existing relationships with each other, and deep and broad relationships with marae and communities. The investment into a partnership approach has engendered a respectful and reciprocal learning relationship that will enrich the outcomes of the research not just for the participants, but for their communities as well.

Te Kahui Matua Advisory Group: One of the earliest resources established to support and guide the MOKO project was in the form of an advisory group that reflects the communities of South Auckland. This forum, known as Te Kahui Matua, has an independent overview of the MOKO project and brings cultural, professional, and ethical critique and guidance to the partnership obligations of the research. Te Kahui Matua meet quarterly and monitor the progress of the project.

Marae Research Co-ordinators: The formalising of the roles of Marae Research Coordinators, who are supported by NWaTT research team to build research capacity and capability for each participating marae, is a key result to date, though this remains a work in progress. The MRCs are integral to gaining insights relevant to their marae communities, as their roles are also important in terms of their respective knowledge and understanding of whānau, hapū, iwi, and community aspirations.

The NPNM and the essential responsibility each MRC has had to connect each marae whānau to the MOKO project and the surrounding community is well acknowledged. Their role has been key to understanding who we needed to involve with MOKO via hui, interviews, and surveys, what the best approach would be for each particular marae, and how we help the marae whānau express their aspirations, set priorities, and access the right level of support and expertise to bring these to life. There has been a rich exchange of insights into the unique aspects and workings of each marae and, simultaneously, an increased interest and aptitude in research as an instrument for helping to advance the vision and mission of marae. Equally, there was a realisation in the early stages of the research of the complexities and commonalities that these five marae are required to navigate and negotiate in the urban landscape. Our breakthrough moments that have endorsed $\mathrm{MOKO}$ as a progressive research piece with regard to our chosen methods can be celebrated. While MRCs have contributed their insights to the themes of writing for publication, as the project continues, they will be more likely to be involved in writing for publication.

Wānanga: Wānanga have been an important aspect within the research context in facilitating a process with NPNM to participate in stimulated discussion and free-flowing dialogue with experienced Kaupapa Māori researchers about a wide range of research projects. Themed wānanga and the involvement of 'guest' speakers from the wider MOKO research team brought topics to the table that were both relevant and pragmatic for the MRCs, who also added value to discussion. These topics included:

- Marae-based kāinga, infrastructure, and facilities;

- Innovative marae-based commercial enterprises;

- Housing pathways for marae;

- $\quad$ Seeing ourselves in the numbers-quantitative analysis;

- Environmental scanning;

- Whakapakari whānau (strengthening whānau); 
- $\quad$ Soil and food sovereignty;

- Urban planning and policies.

Comments made by the MRCs also highlighted the benefits of these wānanga:

- It definitely had participants' brains ticking over about opportunities;

- Participants gained an appreciation of the wide range of skills across the research team;

- Participants gained more clarity from reading information and then talking through it in the hui;

- Participants felt privileged to be able to tap directly into established knowledge and experience.

The value of hosting these interactive forums was expressed consistently by NPNM, who highlighted the wānanga as beneficial for grounding them in the MOKO project and improving their efficacy. The comments shared include the following:

- The time to be together and raise our heads (above the day-to-day grind), to think about collective solutions to common issues across each marae was invaluable;

- Participants really enjoyed the Zoom breakout rooms and the opportunity to share their different perspectives and learn about each other;

- Being together frequently has strengthened the synergy between marae.

- The kōrero helped to bring all the jigsaw pieces of the project together;

- Sharing each other's different ways of presenting information helped participants gain some direction and more confidence to move forward knowing they were on the right track;

- It was good to be challenged and stretched to thinking beyond their own experience by the group;

- The benefits of belonging to the MOKO projects have been the access to expertise, information, and resources, sharing what we learn as we grow, being able to move beyond focusing on the challenges and look more positively about the potential, having the time to reflect, dreaming beyond 'the same'.

Policy Implications: The policy implications that have begun to emerge at this stage of the research project are, firstly, about the research methodology; that is, the importance of asserting culturally relevant research methods that require a shared research-researcher partnering. The leadership at the MOKO advisory level is inclusive of known community leaders who bring local knowledge of their communities and experience with Indigenous research models. This partnering is demonstrated at the research project advisory level, with leaders from each of the marae, and with the appointment of the MRCs. These forums have provided access to a rich source of willing innovative thinkers, local community dynamics and experience, extensive cultural knowledge, and networks. Their overarching interest is to strengthen relationships across communities and with marae, and bring positive change to the landscape of community social deprivation in South Auckland.

The conceptualisation of marae as centres for resilient communities and the extension of the lessons of targeted Kaupapa Māori research to other struggling urban communities represents significant potential to bring benefits to the whole of New Zealand. Therefore, the replenishing of marae to be able to support kāinga prospects needs to be captured via platforms similar to $\mathrm{MOKO}$ to be able to articulate the experience, aspirations, and findings from existing marae-led interventions. Forums such as Te Kahui Matua Advisory Group help generate effective partnerships for researchers and marae, and model the benefits of more collaborative approaches to deliberate solutions to community wellbeing. Their individual and collective profiles and influence determine a greater probability of their credibility and involvement, with the research being recognised and the findings being heard by those charged with developing social policy.

In Year Two of the MOKO project, interviews with marae, local community, and stakeholder agencies, as modelled by the research, aim to generate sustainable marae-led kāinga conversations and initiatives collaboratively alongside communities. The CBPR and 
Kaupapa Māori project approach has already created interest from other stakeholders, who recognise the potential for greater outcomes in community wellbeing. External stakeholders are openly communicating a willingness to better align their community wellbeing policies and land-development planning consultation forums to have greater input and influence from marae.

The second policy implication that has begun to emerge is that the expertise of maraebased solutions to Māori community wellbeing, inclusive of housing, is acknowledged as the people who live in, work in, and love their communities, and who are part of their marae communities. The intent is for marae is to be able to reveal their aspirations in this space and develop these further with evidence-based tools and learnings through the MOKO research findings and the network of expertise from within the research project and across the marae collective communities. The growth of research capability realised through the MRC to date indicates the likelihood of increased confidence within each marae community to engage proactively in their own specific marae-led research areas of interest, as well as contribute to one of the MOKO outcomes, to develop emerging researchers, and build marae research capacity.

The impact of wānanga as a contributor to policy development is widely recognised and practised within Kaupapa Māori institutions across New Zealand. Wānanga is known to provide multiple avenues and occasions for ako (teaching and learning) within marae and communities, as well as between marae and communities, and stakeholders. The opportunity to gain new knowledge from each other through the collaborative processes of both CBPR and Kaupapa Māori has been an important implementation drawn from this research project. The positive outcomes from wānanga as a research method and the learnings gained from participating in wānanga are shared throughout the various MOKO literature outputs.

Other points to note about policy implications that emerge from this research project are: policies that challenge communities to be the solution to their own problems need to factor in the level of resources required to implement responsive processes; and providing enough resources to properly engage with Indigenous perspectives and respect the time needed to maintain relationships that will sustain long-term community wellbeing outcomes has to be realistically factored into research proposals.

Finally, policies for housing development that target answers for Māori needs should ensure holistic approaches to wellbeing are applied, rather than the typical siloed approaches often utilised in addressing issues of wellbeing. As stated by Raerino, "While New Zealand health systems are adapting their strategies to support holistic and empowered Māori health provision, there remains further opportunities for increased cultural -collective health approaches within Māori communities" (Raerino 2017, p. 88). In order to impact Māori housing positively, cultural, social, environmental, and spiritual implications must be encompassed.

\section{Conclusions}

Ngā Wai a Te Tūī is a Kaupapa Māori and Indigenous research entity that sits under the governance of a mainstream polytechnic tertiary institution. The academic credibility and renowned profile of the MOKO team of researchers to the Māori community both locally and nationally, and some to Indigenous communities internationally, signify the emphasis on relationships across Māori communities and with other Māori and Indigenous researchers. Importantly, the MRCs and NPNM also hold credibility with their own respective marae communities - they are the gel. Through the project, the NPNM have built and strengthened relationships between the participating marae, sharing their thinking, dreams, and aspirations; but also sharing knowledge, information, networks, and resources. The synergy created between the MRCs, and again between the MRCs and Ngā Wai a Te Tūi research team, is significant in that it has galvanised existing skills. The benefits of wānanga also offer both a think tank approach as well as a sounding board for the MRCs. 
Reimagining kāinga ora varies from marae to marae, depending on the land area, natural environment, and resources available. Today, urban Māori whānau are generally physically separated from urban marae due to the pressures of housing affordability, housing availability, and whānau circumstances, underpinned by nuclear-family-oriented local and central government policies and practices. While many marae will be, or are already, seeking to add housing typologies to their marae environments, we envisage that notions of 'kāinga ora' may evolve to include a range of spatial connectivities between housing and marae environments, where marae ora has a broad and deep impact on Māori community wellbeing. Such understandings of 'kāinga ora' will enable urban marae to design, expand, and strengthen their reach into their communities. Housing solutions as such will likely draw from the traditional concept of kāinga with multi-generational design becoming a 'renewed' norm. With the overall concept of 'kāinga ora', a holistic view of housing provision must further consider how families are supported to live healthy lifestyles, particularly so in that many in these communities are low-income families, beneficiaries, or in low-paid work. The work performed through the MOKO project further positions the marae involved to contribute to urban planning and design in an approach that is informed and relevant. With the MOKO project halfway through its three-year duration, it is already evident that building marae research capacity and capability works to further strengthen marae confidence in providing for whānau, hapū, iwi, and wider community aspirations.

The marae involved in the MOKO project have, since the project beginnings, honed their existing skill base in response to the threat of the COVID-19 pandemic, each in their own distinct way. With one marae being a long-standing local organic grower for many years, alongside another initiative of repurposing food sources, and establishing itself as a food distribution centre during COVID-19 lockdowns, food and soil sovereignty comes to the fore as a vital source of wellbeing. A second marae, situated on ancestral lands, also re-instituted the practice of growing food to provide for those living in the kāinga, as well as establishing a seed bank to further strengthen food security. Several of the marae also offer education, health, and social services in their communities, with one establishing itself initially as a COVID-19 testing station and then in 2021 setting up as a COVID-19 vaccination centre. These responses illustrate how marae involved in the project are not simply focused on the possibility of housing per se, but more so on the overall health and wellbeing of their communities. The project to date shows that, though there is a primary focus on housing provision, marae will, where they can, take on initiatives that can positively impact on wider issues specific to health and wellbeing. While affordable, adequate, safe housing is at the forefront of this research, wider aspirations of health and wellbeing are further illustrated in the ways in which these marae navigate possibilities for their communities.

Author Contributions: Conceptualisation, methodology, investigation, supervision, funding acquisition, writing, review, and editing of manuscript, J.L.-M.; Conceptualisation, writing of original draft preparation, investigation, resources, writing - review, and editing of manuscript, K.P.; Methodology, formal analysis, writing, review, and editing of manuscript, J.M.; Funding acquisition, writing, review, editing, and project administration, N.E. All authors have read and agreed to the published version of the manuscript.

Funding: This research was funded by NZ Ministry for Business, Innovation and Employment Endeavour Fund, CONT-62695-ENDRP-UNITEC, 2019-2022.

Institutional Review Board Statement: This study received ethics approval from the UNITEC Research Ethics Committee in Auckland, Aotearoa New Zealand (UREC Registration Number: 2020-1040, date of approval 28 September 2020).

Informed Consent Statement: Informed consent was obtained from all subjects involved in the study. 
Acknowledgments: Special acknowledgement to the five South Auckland marae involved in the research: Makaurau Marae, Ihumaatao, Māngere; Papatūānuku Kōkiri Marae, Māngere; Mataatua Marae, Māngere; Manurewa Marae, Manurewa; Papakura Marae, Papakura. Most important, particular mention to Ngā Puna o Ngā Marae who contributed to this article. Tangata ako ana i te kāenga, te tūranga ki te marae, taua ana; A person nurtured in the community contributes strongly to society. Nei ra he mihi mahana ki Ngā Puna o Ngā Marae. Ngā mihi hoki ki a Marie Shannon mo tana tautoko ki tenei tuhinga.

Conflicts of Interest: The authors declare no conflict of interest. The funders had no role in the design of the study; in the collection, analyses, or interpretation of data; in the writing of the manuscript, or in the decision to publish the results.

\section{Glossary}

\begin{tabular}{|c|c|}
\hline Ahi kaa & $\begin{array}{l}\text { (home fires), refers to the home people who keep the home } \\
\text { fires burning }\end{array}$ \\
\hline Ira atua & life principle, of the Gods \\
\hline Ira tangata & life principle, the essence of human life \\
\hline Iwi & tribe \\
\hline Hapū & sub-tribe \\
\hline Kai & food, sustenance \\
\hline Kāinga & home, housing, village, settlement, community \\
\hline Kaitiakitanga & guardianship, stewardship, protector \\
\hline Kaupapa Māori & Māori-led \\
\hline Kawa & customs \\
\hline Karakia & prayer, ceremonial chant \\
\hline Manaakitanga & to care for, host, look after \\
\hline Māori & First Peoples of Aotearoa, tangata whenua \\
\hline Marae Ora Kāinga Ora & Marae Wellbeing, Community Wellbeing \\
\hline Marae & primary places/places for cultural gatherings \\
\hline Mātauranga & knowledge \\
\hline Mātauranga Māori & Māori knowledge \\
\hline Mātāwaka & kinship group, tribe \\
\hline Mātua Rautia & a hundred parents \\
\hline Mihimihi & greetings and acknowledgements \\
\hline Ngā Wai a Te Tūī (NWaTT) & The Waters of The Tui (bird native to Aotearoa) \\
\hline Noa & common \\
\hline Ora & wellbeing \\
\hline Pākehā & a person of European descent, fair-skinned \\
\hline Papatūānuku & Earth Mother, ancestral mother \\
\hline Rangatira & chief, leader \\
\hline Ranginui & Sky Father, ancestral father \\
\hline Tapu & sacred \\
\hline Tangata whenua & people of the land, Indigenous people, First Peoples \\
\hline Taura here & urban kinship group \\
\hline Tikanga & cultural protocols, Māori law \\
\hline Tino rangatiratanga & self-determination, authority \\
\hline Tohi & ceremonial blessing ritual \\
\hline Whakapapa & genealogy, ancestral ties \\
\hline Whakawhanaungatanga & process of establishing relationships \\
\hline Whānau & family, extended family \\
\hline
\end{tabular}

\section{References}

Adds, Peter, Meegan Hall, Rawinia Higgins, and Te Ripowai Higgins. 2011. Ask the Posts of our House: Using Cultural Spaces to Encourage Quality Learning in Higher Education. Teaching in Higher Education 16: 541-51. [CrossRef]

Auckland Council. 2018. Auckland Plan 2050 (Full Print Version); Auckland: Auckland Council. Available online: https: / / www.aucklandcouncil.govt.nz/plans-projects-policies-reports-bylaws/our-plansstrategies/auckland-plan/about-theauckland-plan/Pages/supporting-documents.aspx (accessed on 6 April 2020). 
Awatere, Shaun, Craig Pauling, Shad Rolleston, Rau Hoskins, and Karl Wixon. 2008. TūWhare Ora—Building Capacity for Māori Driven Design in Sustainable Settlement Development. Auckland: Landcare Research.

Barnes, Helen, and Tim McCreanor. 2019. Colonisation, Hauora and Whenua in Aotearoa. Journal of the Royal Society of New Zealand 49: 19-33. [CrossRef]

Belich, James. 1986. The New Zealand Wars and the Victorian Interpretation of Racial Conflict. Auckland: Auckland University Press.

Bennett, Adrian. 2007. Marae. A Whakapapa of the Māori Marae. Doctoral thesis, University of Canterbury, Christchurch, New Zealand.

Building Better Homes, Towns and Cities. 2015. National Science Challenge 11. Wellington: Building Better Homes, Towns and Cities, Available online: https://www.buildingbetter.nz/publications/BBHTC.pdf (accessed on 3 August 2021).

Durie, Mason. 1994. Whaiora. Auckland: Oxford University Press.

Durie, Mason. 1998. Te Mana te Kawanatanga. Auckland: Oxford University Press.

Durie, Mason. 2004. Ngā Kahui Pou: Launching Māori Futures. Wellington: Huia Publishers.

Education Act. 1989. Available online: https:/ / www.legislation.govt.nz/act/1989/0080/latest/whole.html. (accessed on 21 July 2021).

Eketone, Anaru. 2008. Theoretical Underpinnings of Kaupapa Māori Directed Practice. MAI Review 1. Available online: http: / / hdl.handle.net/10523/7084 (accessed on 2 August 2021).

Eruera, Moana, and Leland A. Ruwhiu. 2016. Ngā Karangaranga Maha o te Ngākau o Ngā Tüpuna: Tiaki Mokopuna. Ancestral Heartfelt Echoes of Care for Children. Winnipeg: Cambridge Scholars Publishing.

Hokowhitu, Brendan. 2013. Producing Indigeneity. In Indigenous in the City: Contemporary Identities and Cultural Innovation. Edited by Evelyn Peters and Chris Andersen. Vancouver: UBS Press, pp. 354-76.

Hoskins, Rau, Jenny Lee-Morgan, Wayne Knox, Hurimoana Dennis, Lena Henry, Leisa Nathan, Reuben Smiler, and Maia Ratana. 2019. Tūranga ki te Marae, e Tau Ana: Reimagining Marae-based Kāinga in Tāmaki Makaurau. Auckland: Ngā Wai a Te Tūī Press.

Israel, Barbara, Chris Coombe, Rebecca Cheezum, Amy Schulz, Robert McGranaghan, Richard Lichtenstein, Angela Reyes, Jaye Clement, and Akosua Burris. 2010. Community-based Participatory Research: A Capacity-building Approach for Policy Advocacy Aimed at Eliminating Health Disparities. American Journal of Public Health. Available online: https://ajph.aphapublications.org/ doi/full/10.2105/AJPH.2009.170506 (accessed on 10 June 2020).

Ka'ai, Tania. 2008. The Role of Marae in Tertiary Education Institutions. Te Kaharoa 1: 193-202. Available online: https://www. tekaharoa.com/index.php/tekaharoa/article/view/133/124 (accessed on 8 April 2020).

Kawharu, Merata, ed. 2014. Maranga Mai! Te Reo and Marae in Crisis? Auckland: Auckland University Press.

Kelsey, Jane. 1995. The New Zealand Experiment: A World Model for Structural Adjustment? Auckland: Auckland University Press with Bridget Williams Books.

Lee-Morgan, Jenny, Rau Hoskins, Rihi Te Nana, Rua Mohi, and Wayne Knox. 2019. In Service to Homeless Whānau in Tāmaki Makaurau; Report of the Manaaki Tāngata Programme at Te Puea Memorial Marae for Building Better Homes, Towns and Cities: Kāinga Tahi, Kāinga Rua. Auckland: Te Puea Memorial Marae. Available online: https://www.buildingbetter.nz/publications/ktkr/ Lee-Morgan_et_al_2019_Manaaki_Tangata_Prog_TPMM.pdf (accessed on 18 June 2020).

Lloyd, Tamarapa. 2018. He Oranga mo Aotearoa: Māori Wellbeing for All. In State of the State 2018. Wellington: Deloitte and Victoria University of Wellington, Available online: https:/ /www2.deloitte.com/content/dam/Deloitte/nz/Documents/public-sector/ Deloitte\%20NZ\%20SotS\%202018\%20Article\%209.pdf (accessed on 13 July 2021).

Mahuika, Rangimarie. 2008. Kaupapa Māori Theory is Critical and Anti-colonial. MAI Review 3: 4. Available online: http://www. review.mai.ac.nz/mrindex/MR/article/download/153/153-877-1-PB.pdf (accessed on 19 July 2020).

Mane, Jo. 2009. Paho Māori. Ph.D. thesis, The University of Auckland, Auckland, New Zealand.

McClintock, Kahu, Ana Sokratov, Graham Mellsop, and Te Kani Kingi. 2013. Hua Oranga: Service Utility Pilot of a Mental Health Outcome Measurement for an Indigenous Population. The International Indigenous Policy Journal 4: 1-14. [CrossRef]

McIntosh, Tracey, and Malcolm Mulholland, eds. 2011. Māori and Social Issues. Wellington: Huia Publishers.

Menzies, Diane, Jay Whitehead, Grace Walker, John Reid, and Angus MacFarlane. 2019. Economics and Financing of Housing for Māori-Literature Review. Report for Building Better Homes, Towns and Cities: Whai Rawa Whenu, Kāinga Tahi, Kāinga Rua. Wellington: Building Better Homes, Towns and Cities, Available online: https:/ /www.buildingbetter.nz/publications/ktkr/ Menzies_et_al_2019_Econ_\&_Financing_Literature_Review_Whai_Rawa_KTKR.pdf (accessed on 23 July 2020).

Mikaere, Ani. 2011. Colonising Myths_Māori Realities: He Rukuruku Whakaaro. Wellington: Huia Publishers.

O'Malley, Vincent. 2019. The New Zealand Wars: Ngā Pakanga o Aotearoa. Wellington: Bridget Williams Books.

Pihama, Leonie, Fiona Cram, and Sheila Walker. 2002. Creating Methodological Space: A Literature Review of Kaupapa Māori Research Canadian Journal of Native Education 26: 30. Available online: http://www.ngapoumana.org.nz/uploads/9/8/8/2/98823026/200 2_pihama_cram_walker_creating_methodological_space_a_literature_review_of_kaupapa_m\%C4\%81ori_research.pdf (accessed on 26 May 2020).

Pihama, Leonie. 2012. Kaupapa Māori Theory: Transforming Theory in Aotearoa. He Pukenga Kōrero 9: 5-15.

Pohatu, Taina Whakaatere. 2013. Ata: Growing Respectful Relationships. Ata: Journal of Psychotherapy Aotearoa New Zealand 17: 13-26. [CrossRef]

Raerino, Kimiora. 2017. Marae Food Gardens: Health and Wellbeing Through Urban Marae in Tāmaki Makaurau. Doctoral thesis, The University of Auckland, Auckland, New Zealand. 
Rout, Matthew, John Reid, Di Menzies, and Angus MacFarlane. 2019. Homelessness and Landlessness in Two Generations-Averting the Māori Housing Disaster. Report for Building Better Homes, Towns and Cities; National Science Challenge. Wellington: Building Better Homes, Towns and Cities, Available online: https://www.buildingbetter.nz/publications/ktkr/Rout_et_al_2019 _Homeless_\&_landless_in_two_generations_KTKR.pdf (accessed on 25 May 2020).

Royal, Te Ahukaramū Charles, ed. 2003. The Woven Universe. Selected Writings of Rev. Māori Marsden. Otaki: Estate of Rev. Māori Marsden.

Salmond, Anne. 1994. Hui: A Study of Māori Ceremonial Gatherings. Auckland: Reed.

Smith, Graham Hingangaroa. 1997. The Development of Kaupapa Māori Theory and Praxis. Ph.D. thesis, The University of Auckland, Auckland, New Zealand.

Smith, Linda Tuhiwai, Leonie Pihama, Ngaropi Cameron, Tania Mataki, Hinewirangi Morgan, and Rihi Te Nana. 2019. Thought Space Wānanga: A Kaupapa Māori Decolonizing Approach to Research Translation. International Journal of Environmental and Public Health. Special Issue: Global Indigenous Health: Maintaining Health in the Midst of Disruption. Available online: https://www.researchgate.net/publication/337981195_Thought_Space_Wananga-A_Kaupapa_Maori_Decolonizing_ Approach_to_Research_Translation (accessed on 28 April 2020).

Smith, Linda Tuhiwai. 1999. Decolonising Methodologies: Research and Indigenous Peoples. London: Zed Books.

Suter, Benjamin. 2014. "The Contra Proferentem Rule in the Reports of the Waitangi Tribunal." LLM Research Paper, Laws 547: The Waitangi Tribunal and New Zealand Legal History, Victoria University of Wellington. Available online: http://hdl.handle.net/10 063/4404 (accessed on 7 July 2021).

Tapsell, Paul. 2002. Marae and Tribal Identity in Urban Aotearoa/New Zealand. Pacific Studies 25. Available online: https://www. researchgate.net/publication/279186299_MARAE_AND_TRIBAL_IDENTITY_IN_URBAN_AOTEAROANEW_ZEALAND (accessed on 22 April 2020).

Tapsell, Paul. 2014. Tribal Marae Crisis: What Crisis? In Maranga Mai! Te Reo and Marae in Crisis? Edited by Merata Kawharu. Auckland: Auckland University Press, pp. 35-64.

Te Aho, Linda. 2007. Tikanga Māori, Historical Context and the Interface with Pākehā Law in Aotearoa/New Zealand. In Yearbook of New Zealand Jurisprudence. Wellington: Thomson Reuters.

Te Puni Kōkiri. 2018. Annual Report for the Year Ended 30 June 2018; Wellington: Te Puni Kōkiri. Available online: https: / / www.tpk.govt. nz/en/a-matou-mohiotanga/corporate-documents/annual-report-for-the-year-ended-30-june-2018 (accessed on 7 April 2020).

Waitangi Tribunal. n.d. Translation of the Te Reo Māori Text. Available online: https://waitangitribunal.govt.nz/treaty-of-waitangi/ translation-of-te-reo-m\%C4\%81ori-text/ (accessed on 16 June 2020).

Walker, Ranginui. 1990. Ka Whawhai Tonu, Struggle Without End. Auckland: Penguin Books.

Williams, Herbert W. 2015. Dictionary of the Māori Language. Wellington: Printlink.

Wirihana, Rebecca, and Cherryl Smith. 2014. Historical Trauma, Healing and Well-Being in Māori Communities. Mai Journal 3: 197-210. Available online: http:/ / www.journal.mai.ac.nz/sites/default/files/MAI_Jrnl_3\%283\%29_Wirihana02.pdf (accessed on 14 July 2020).

Workman, Kim. 2016. From a Search for Rangatiratanga to a Struggle for Survival—Criminal Justice, the State and Māori, 1985 to 2015. The 2015 JD Stout Lecture. The Journal of New Zealand Studies 22: 90. [CrossRef] 